\title{
Surveilling the Mind and Body: Medicalising and De-medicalising Homosexuality in 1970s New Zealand
}

\author{
JAMES E. BENNETT ${ }^{1 *}$ and CHRIS BRICKELL ${ }^{2 *}$ \\ ${ }^{1}$ School of Humanities \& Social Science, The University of Newcastle, Australia, University Drive, \\ Callaghan, NSW2308, Australia \\ ${ }^{2}$ Department of Sociology, Gender \& Social Work, Otago University, PO Box 56, \\ Dunedin, New Zealand
}

\begin{abstract}
Medicalisation' of same sex relations is a phenomenon that reached its peak in the 1950s and 1960s. The rise of gay liberation produced a divisive political contest with the psychiatric profession and adherents of the orthodox 'medical model' in the United States and - to a lesser extent - in the United Kingdom. This socio-historical process occurred throughout the English-speaking world, but much less is known about its dynamics in smaller countries such as New Zealand where the historiography on this issue is very sparse. The methodology situates New Zealand within a transnational framework to explore the circulation of medical theories and the critical responses they were met with. The article is anchored around three key local moments in the 1970s to consider the changing terrain on which ideas about homosexuality and psychiatry were constantly rearranged during this decade. This power struggle took a number of twists and turns, and the drive toward medicalisation alternated with a new impetus to de-medicalise same-sex sexuality.
\end{abstract}

Keywords: Homosexuality, Psychiatry, Medicalisation, De-medicalisation, New Zealand, 1970s

The modern gay and lesbian movement, the struggle against the oppression of gay men and lesbians, is historically in a certain sense a struggle against medicine. ${ }^{1}$

In 1964, 20-year old Ralph Knowles, a homosexual man living in Dunedin, New Zealand who was not 'unhappy' with his sexuality and saw a future for himself as a

*Email addresses for correspondence: j.bennett@newcastle.edu.au, chris.brickell@ otago.ac.nz Our appreciation is extended to staff at the Alexander Turnbull Library in Wellington - particularly Phil Parkinson and Roger Swanson - for guidance in use of the Lesbian and Gay Archives (LAGANZ), to staff of the Hocken Collections at the University of Otago, and to Bill Logan and Ralph Knowles for their suggestions in researching and writing this article. We also thank reviewers of the article for their thoughtful feedback.

${ }^{1}$ Bill Logan (for the Gay Task Force), 'Doctors and Gays: A Difficult Relationship', an unsolicited paper prepared for the National Conference on AIDS, Wellington Hospital, 12-13 November 1987, 2. MS 199, Lesbian and Gay Archives New Zealand (hereafter LAGANZ), Alexander Turnbull Library (ATL), Wellington, New Zealand. 
theological student, identified 'serious conflicts' between his sexual identity and religious aspirations. ${ }^{2}$ Knowles identified the concern to his confessor, and despite misgivings about the efficacy of any proposed course of 'treatment' he complied with the confessor's advice that he should seek help in addressing his 'problem'. Dr Basil James, then a clinician at the University of Otago, who went on to carve out an eminent career in mental health in the 1970s and 1980s, interviewed Knowles and advised him to undertake a programme of aversion therapy. According to contemporary behaviourist theory, the patient's sexuality could be altered through the process of conditioning. The course of 'treatment' consisted of an initial five-day session of drug therapy. This involved injections of a nausea-inducing preparation called apomorphine in conjunction with a measure of whisky. The other essential resource was what Knowles later described as a 'rather pathetic tape' comprising the homoerotic fantasies he had outlined for use by the clinician. The apomorphine was injected prior to listening to the tape to ensure the patient would vomit as his fantasies were played back to him.

On the verge of withdrawing from the programme, Knowles was persuaded to complete the 'treatment'. Far from being 'cured', though, the patient later reported feeling he had returned to a sense of 'normality'. This precipitated a further session of drug therapy some months later, this time involving the injection of hormones to increase (heterosexual) desire. Separate out-patient sessions of electric shocks to the hand were administered in an attempt to suppress homoerotic responses to pleasurable stimuli. The treatment programme succeeded only in the narrow and perverse sense that it produced a permanent aversion in the patient to whisky. In the end, it merely confirmed for Knowles the authenticity of his original sexual orientation. He was transformed, moreover, into an implacable opponent of the treatment's application, considering it to be 'psychiatrically crude and physically barbaric - not to mention medically ineffective, morally wrong, and socially outrageous'. 3

Knowles' experience of aversion therapy is so far the only documented account we have from New Zealand, and yet this was a behavioural treatment that was commonly administered to homosexual men in the West during the post-war era. This technique became a particular focus of gay activism during the 1970s. To date, the history of psychiatric treatments given to 'cure' gay people has largely been a North American and European story; we have a much more limited understanding of how this story played out in other parts of the world such as New Zealand and Australia. ${ }^{4}$ The figure of Basil James, who migrated from the United Kingdom to New Zealand, provides us with one useful pathway to develop this understanding. He held many positions in the Royal College

\footnotetext{
2 Knowles' encounter with aversion therapy is told in a number of accounts, both published and unpublished including in the Christchurch-based gay liberation newsletter, Aequus. See Ralph Knowles, 'Kick, Kill or Cure', Aequus: Southern Gay Community Newsletter, 3 (May 1976), 10-12 (reprinted September 1978, 5, 17-20).

${ }^{3}$ Ibid. (note 2). See the chapter 'Ralph' in B.R. Simon Rosser, Gay Catholics Down Under: The Journeys in Sexuality and Spirituality of Gay Men in Australia and New Zealand (Westport, CT: Praeger, 1992), especially 16-17. 'Enough to Make You Sick - Aversion Therapy', Queer History New Zealand, http://www. gaynz.net.nz/history/Aversion.html (accessed 16 November 2015). Also see an anonymous account outlined in G. Ngaei, 'Homosexuality and it's [sic] Implications' (Social and Preventive Medicine for the Third Professional Examination for the Degree, University of Otago, 1967), 19-22. The subject in this account was Ralph Knowles. Personal communication with Ralph Knowles, 28 February 2017.

${ }^{4}$ Similarly, there is still a significant gap in knowledge about our understanding of how homosexual people were treated in psychiatric institutions, which was commonplace before social attitudes began to liberalise in the late 1960s. See Ivan Crozier, review of Tommy Dickinson, 'Curing Queers': Mental Nurses and their Patients, 1935-74 (Manchester: Manchester University Press, 2015), H-Histsex (H-Net Reviews) (December 2015).
} 
of Australian and New Zealand Psychiatry including the role of President from 1977 to 1979. James became Professor of Psychological Medicine at the University of Otago in Dunedin, and went on to hold professorial positions at the University of Queensland and James Cook University in Townsville. James trained in the United Kingdom where he had previously used aversion therapy while registrar at a hospital in Bristol, and reported it to be successful in the treatment of an exclusively homosexual man. ${ }^{5}$ In this sense we can situate him as a transnational vector of influence in the rise of the 'therapeutic state', which saw most treatments administered in an unregulated way without adherence to any ethical guidelines. $^{6}$

The New Zealand situation broadly reflected international patterns, although the significantly larger anglophone countries of the United States and the United Kingdom experienced much more dramatic moments in the complex untangling of this story. Radical gay activism against medicalisation and the psychiatric profession in early 1970s America - symbolised by Dr Henry Anonymous' compelling address at the American Psychiatric Association's 1972 conference in Dallas - is the most visible moment in popular historical consciousness. ${ }^{7}$ At about the same time, the prominent UK gay activist Peter Tatchell clashed with psychiatrists at a symposium on aversion therapy convened by the London Medical Group where psychiatrist Isaac Marks claimed that aversion therapy was 'just like a visit to the dentist'. The verbal wrangle that followed reportedly led to Tatchell being 'violently assaulted' and removed from the venue. $^{8}$ The travails of gay liberation were not solely responsible for a decisive shift that took place in the relationship between psychiatry and homosexuality in the early 1970s. Other factors such as changing media coverage and the influential American Psychiatric Association's landmark decision to delist homosexuality from the Diagnostic and Statistical Manual of Mental Disorders (DSM) were also critical in slowing the rate of therapies used to try to convert gay people. ${ }^{9}$ A further contributing factor on which psychiatric narratives are generally silent was the abject failure of these therapies. ${ }^{10}$ An oral history paper into treatments has disclosed that some mental health professionals in Britain believed they were justifiable, but 'many had increasing doubts about efficacy and ethics'. ${ }^{11}$

In a recent article on the United States, Abram Lewis suggests this struggle was more than a matter of gay resistance to psychiatry and that the very status of psychiatry came under scrutiny. At stake was not only psychiatrists' ability to define homosexuality in the

\footnotetext{
${ }^{5}$ See B. James, 'Case of Homosexuality Treated by Aversion Therapy', British Medical Journal, 1 (1962), 76870; B. James and D. Early, 'Aversion Therapy for Homosexuality', British Medical Journal, 1, (1963), 538.

${ }^{6}$ See T. Dickinson, 'Curing Queers': Mental Health Nurses and their Patients, 1935-74 (Manchester: Manchester University Press, 2014), especially 67 and 69, and M. King, G. Smith and A. Bartlett, 'Treatments of Homosexuality in Britain since the 1950s - An Oral History: The Experience of Professionals', BMJ, 328 (2004), doi:10.1136/bmj.37984.496725.EE.

${ }^{7}$ R. Bayer, Homosexuality and American Psychiatry: The Politics of Diagnosis (New York: Basic Books, 1981), 13. J. Drescher and J.P. Merlino (eds), American Psychiatry and Homosexuality: An Oral History (New York: Harrington Park Press, 2007), see especially xvii and 2.

${ }^{8}$ Dickinson, op. cit. (note 6), 211.

${ }^{9}$ Ibid., 222. A parallel diagnostic tool called the ICD was established by the World Health Organization and used interchangeably with the DSM in the UK. Significantly, homosexuality was not formally removed from this classification paradigm until publication of the 10th edn of the ICD in 1992. See Dickinson, op. cit. (note 6), 242-3.

${ }^{10} \mathrm{We}$ are indebted to Ivan Crozier for this observation.

${ }^{11}$ King et al., op. cit. (note 6).
} 
public consciousness and subject gay patients to its 'cures', but the role of psychiatry as an arbiter of the normal. ${ }^{12}$ What did homosexuality, psychiatry and health mean in a changing society? These questions arose in New Zealand too. Ralph Knowles' sessions of aversion therapy spoke not only to his own desires, but also to the power by which homosexuality was defined and controlled. This article considers the changing terrain on which ideas about homosexuality and psychiatry were constantly rearranged during the 1970s. This power struggle took a number of twists and turns, and the drive toward medicalisation alternated with a new impetus to de-medicalise same-sex sexuality.

\section{Medicalisation, De-medicalisation}

When we chart the shifts in professional opinion, Lewis suggests, it is hard to identify a moment of greater international impact than the American Psychiatric Association's 1973 decision to de-list same sex behaviour from the nomenclature of the DSM. ${ }^{13}$ An intense tussle between gay activists and some members of the psychiatric profession ensued: was the gay person ill or not? A milder version of this conflict played out in other anglophone countries including Australia, where prominent adherents of aversion therapy such as Sydney-based Dr Neil McConaghy (who regularly published his findings), attracted the ire of gay activists. ${ }^{14}$ Moreover, two leading figures in the Australian gay liberation group CAMP (Campaign Against Moral Persecution), Sue Wills and John Ware, cited the danger of psychiatric theory as a key motivation behind their activism. ${ }^{15}$ Little has been written about resistance to psychiatric therapy in New Zealand where the political contest against the 'medical model' was less visible. The reasons for this are not entirely clear, although the absence of polarising psychiatrists to rally against, including psychoanalysts Charles Socarides and Irving Bieber in the United States, is a likely factor. ${ }^{16}$ For Australian historian Graham Willett, the key difference between the United States on the one hand and Australia and New Zealand on the other was the absence in the antipodes of deeply held theoretical positions within the profession. Conversely, the very presence of this phenomenon in North America would provoke a fierce contest in response to the challenge of 'de-medicalisation' ${ }^{17}$ Despite the gaps in our understanding of this process in Australia, we nevertheless have at least an appreciation of its broad contours including published empirical data on the views of psychiatrists and clinical psychologists that underpinned

\footnotetext{
12 A. Lewis, " "We Are Certain of Our Own Insanity": Antipsychiatry and the Gay Liberation Movement', Journal of the History of Sexuality, 25 (2016), 83-113.

13 Ibid., 84.

${ }^{14}$ See, for example, G. Willett, Living Out Loud: A History of Gay and Lesbian Activism in Australia (Sydney: Allen \& Unwin, 2000), especially 101-7; E. Wilson, "Someone who is sick and in need of help": medical attitudes to homosexuality in Australia, 1960-79', in S. Robinson (ed.), Homophobia: An Australian History (Sydney: The Federation Press, 2008), 148-71; E. Wilson, 'Homosexual health hazards": public discourse on homosexuality and medicine in Australia, 1973-84', in Y. Smaal and G. Willett (eds), Out Here: Gay and Lesbian Perspectives VI (Melbourne: Monash University Publishing, 2011), 69-87.

15 Willett, Living out Loud, ibid., 102, 104. For a first-hand account of the debate with psychiatrists who practised aversion therapy - with particular reference to McConaghy - see Sue Wills, 'The Politics of Sexual Liberation' (unpublished PhD thesis: University of Sydney, 1981), especially 87-91.

${ }^{16}$ See D. Altman, Homosexual Oppression and Liberation (Brisbane: University of Queensland Press, 1971; citations from 2012 edn, 141-2.

${ }^{17}$ G. Willett, 'Psyched In: Psychology, Psychiatry and Homosexuality in Australia', Gay and Lesbian Issues and Psychology Review, 1 (2005), 53-7.
} 
key developments in the early 1970s. ${ }^{18}$ In contrast, the very limited scholarship on 'demedicalisation' in New Zealand historiography has left a more opaque picture. ${ }^{19}$

Michel Foucault and Jennifer Terry offer valuable insights into the modes of resistance developed as gay subjects negotiate scientific and medical authority. Foucault reminds us that power never operates in a totalising way. His philosophical and historical writings understand power as relational rather than completely vested in the figure of the doctor. Foucault articulated the concept of micro-powers at an everyday level. Individuals resist regulation by refusing to submit to medical techniques and practices. ${ }^{20}$ Moreover, as Terry has noted, compliance and resistance to pathologising constructions of sexuality can be located at different moments in the same subject. ${ }^{21}$ This article will focus on three critical moments in 1970s New Zealand, each of which demonstrates a dialectic over the meaning and acceptability of homosexuality. These key moments are: (1) the clinical memorandum issued by the Australian and New Zealand College of Psychiatrists (ANZCP) in October 1973 that put forward a liberal line on homosexuality; (2) the debate over the unsuccessful 1974-5 Crimes Amendment Bill, which aimed to decriminalise consenting sex between adult men in private; and (3) two detailed 1977 surveys co-ordinated by Gay Liberation in Wellington. As this discussion unfolds, it is well to keep in mind that there never was a unified viewpoint on homosexuality within the medical profession despite the periodic promulgation of official position statements. Older medical orthodoxies endured, overlapped with and competed for hegemonic status with new medical knowledge. ${ }^{22}$ Sometimes old orthodoxies were marshalled in the aid of emotive political debate against non-conformist sexual behaviour, and a complex, fractured and fluid picture of this era emerges.

The Australian and New Zealand College of Psychiatrists is the key medical organisation in this history. The College had responsibility for the training, accreditation and representation of psychiatrists in both countries, and its documents allow us to chart the shifts in professional opinion on homosexuality. ${ }^{23} \mathrm{~A}$ New Zealand presence was evident from the organisation's inception through the leadership roles of several influential psychiatrists, despite the absence of a formal New Zealand branch before 1955 . The College's predecessor body was founded in 1946 and College policy was formed shortly afterwards, but on contentious social issues it deferred to the Australian Medical Association, believing these issues to more appropriately lie within the domain of that larger medical body. Changing social behaviours and sexual mores in the wider population forced a switch in approach from the late 1960s and led the College to adopt a much more public profile in communicating psychiatric perspectives to the community. ${ }^{24}$

18 Ibid., 55. Willett, op. cit. (note 14), 101-7.

${ }^{19}$ L. Guy, " "Straightening the Queers": Medical Perspectives on Homosexuality in Mid-Twentieth Century New Zealand', Health and History, 2 (2000), 101-20.

${ }^{20}$ D. Lupton, 'Foucault and the medicalisation critique', in Alan Petersen and Robin Brunton, Foucault, Health and Medicine (London and New York: Routledge, 1997), 94-110: 100 and 103.

${ }^{21}$ J. Terry, 'Theorizing deviant historiography: feminist theoretical lineages of deviant historiography: a retrospective preface', in A. Shapiro (ed.), Feminists (Re)Vision History (New Brunswick: Rutgers University Press, 1994), 276-303: 289.

22 We owe this understanding of cultural change to Raymond Williams, The Long Revolution (London: Chatto \& Windus, 1961).

23 The College is but one of a number of joint Australian and New Zealand colleges for health professionals that are responsible for the maintenance of professional standards.

${ }^{24}$ W.D. Rubenstein and H. Rubenstein, Menders of the Mind: A History of the Royal Australian and New Zealand College of Psychiatrists, 1946-96 (Melbourne: Oxford University Press, 1996), 12, 41. 
At the forefront of this shift was the Social Issues Committee, itself founded in the late 1960s, which the College's official historians have characterised politically as 'permissive or left-liberal' and - reflective of College attitudes more broadly - far more progressive than mainstream public opinion. ${ }^{25}$ In truth, a significant body of medical literature through the 1950s and 1960s continued to pathologise homosexuality, or at best to see it as a developmental anomaly. Hostile fathers, dominating mothers, narcisissm, 'incestuous associations' and a range of psychological weaknesses were all blamed for the development of same-sex desires in the individual. ${ }^{26}$ In the New Zealand context, 'Homosexuality as Seen in a New Zealand City Practice', written by Wellington general practitioner E. Philipp and published in the New Zealand Medical Journal in 1968, was a rare example of a pre-1970 article that identified homosexuality as a social problem rather than one that called for medical or psychiatric intervention. ${ }^{27}$ 'Homosexuality in New Zealand is not a problem in itself', Philipp wrote, 'but social pressures are the determining factor in the problems of homosexuality'. ${ }^{28}$ In New Zealand's predominantly public-funded health system it was the general practitioner like Philipp rather than the specialist psychiatrist who encountered homosexuality on a regular basis.

By the early 1970s three major blocks of opinion on homosexuality were identified within the profession:

Psychiatric opinion on the nature of homosexuality varies. The traditional view is that homosexuality is a neurotic disorder. The radical view is that homosexuality is a normal variant like left-handedness. Middle of the road opinion, which the majority of psychiatrists would support, regards homosexuality as a developmental anomaly not necessarily or commonly associated with neurotic symptoms. ${ }^{29}$

A majority of Members and Fellows of the New Zealand branch of the College assented to this statement, an abridged version of the College's 1973 clinical memorandum. It formed part of the submission in 1974 from the College to the New Zealand Parliamentary Select Committee hearing evidence on the Crimes Amendment Bill - a major legislative attempt to decriminalise sexual acts between consenting adult males in private. In view of the rapidly changing nature of psychiatric opinion in the 1970s, the role of the College and its various agencies warrant close consideration. The coming together of medicine and law is highly significant in Foucauldian terms. Gerald Turkel summarises Foucault's suggestion that we regard the law and medicine as expanding and intersecting modes of social control, knowledge production, and the construction of individual subjectivities. ${ }^{30}$ As sets of discourses and social practices, Turkel adds, both enforce standards of normality, often in ways that are mutually informing. As we will demonstrate in the discussion that follows, debates about law and medicine have been closely intertwined in the history of homosexuality.

\footnotetext{
25 Rubenstein and Rubenstein, ibid., 41-4.

${ }^{26}$ See, for example, J.D. Denford, 'The Psychodynamics of Homosexuality', New Zealand Medical Journal, 66 (1967), 743-4.

${ }^{27}$ E. Philipp, 'Homosexuality as seen in a New Zealand City Practice', New Zealand Medical Journal, 67 (1968), 397-405. There is a wider literature responding to homosexuality as a social category rather than a medical condition. See, for example, M. Mackintosh, 'The Homosexual Role', Social Problems, 16 (1968), 182-92.

${ }^{28}$ Philipp, ibid., 397.

${ }^{29}$ Submission by NZ Branch of ANZCP on the Crimes Amendment Bill, 13 November 1974. University Gay Liberation, Auckland. LAGANZ-MS-Papers-69, ATL.

${ }^{30}$ G. Turkel, 'Michel Foucault: Law, Power and Knowledge', Journal of Law and Society, 17 (1990), $170-93$.
} 


\section{Medicine and Law Reform}

In May 1972 the General Council of the ANZCP adopted the following resolution: 'That the ... [College] strongly condemns community attitudes and laws which discriminate against homosexual behaviour between consenting adults in private.' ${ }^{31}$ The point was reiterated in the College's 1973 clinical memorandum. For many years a large number of medical professionals had lent their support to law reform in order to redirect responses away from a regime of punishment meted out by the judiciary and towards the medical domain, thereby enabling treatment. ${ }^{32}$ The clinical memorandum continued to see efficacy in psychiatric treatment directed specifically at those who sought a more successful adaptation to a predominantly heterosexual society - especially among the young and those who had 'experienced some form of heterosexual desire or activity in the past'. ${ }^{33}$ However, the document also highlighted an ethical problem for the majority of contemporary psychiatrists as revealed in a legal obligation imposed by the courts. Some judges waived custodial sentences or fines for those convicted for homosexual offences, on the condition they agreed to psychiatric intervention. Few psychiatrists, though, wanted to associate themselves professionally with subjects unless those subjects were free from the controls of the legal system. ${ }^{34}$

Changing views about homosexuality came to the fore. The clinical memorandum and its conclusions took their cue from a 1973 survey of 110 psychiatrists and 40 clinical psychologists in New South Wales. This revealed a majority attitude that homosexuality 'was not, in and of itself, commonly or necessarily associated with neurotic symptoms' ${ }^{35}$ While one-third of interviewees in this radical-conservative spectrum of opinion continued to believe that 'there is something seriously wrong with a homosexual', others supported attempts to decriminalise sex between men on the grounds there was no psychological reason to advocate criminality. ${ }^{36}$ Similarly, the New Zealand branch of the ANZCP and the New Zealand Psychological Society declared their support for the moderately reformist Crimes Amendment Bill introduced into the Wellington Parliament in 1974 as a private member's bill by Venn Young, a member of Parliament (MP) from the opposition centreright National Party. ${ }^{37}$ As with the 1957 Wolfenden Report, partially enacted in the Sexual Offences Act in Britain a decade later, Young's bill sought decriminalisation of same sex acts between consenting males in private. ${ }^{38}$

In his reading of New Zealand Hansard records, Christopher Burke has drawn attention to the discursive construction of the 'homosexual' through a range of discourses - nature, science, religion and the law - sometimes used separately, other times in combination. Strikingly, during the 1960 s and 1970 s pro-reformers often resorted to normativising or

\footnotetext{
${ }^{31}$ NZ Branch of ANZCP, op. cit. (note 29).

32 Wilson, 'Homosexual Health Hazards', op. cit. (note 14), 72-3.

33 Australian and New Zealand College of Psychiatry, Clinical Memorandum No. 6, 'Homosexuality', Melbourne. October 1973.

34 Ibid.

35 Rubenstein and Rubenstein, op. cit. (note 24), 44; ANZCP, op. cit. (note 33).

36 Willett, op. cit. (note 14), 103; Rubenstein and Rubenstein, op. cit. (note 24), 44.

37 See Submission on Crimes Amendment Bill from NZ Psychological Society, Otago University, 27 September 1974, LAGANZ-PAM 729.75 NZ Psy, ATL.

38 On Wolfenden see B. Lewis, Wolfenden's Witnesses: Homosexuality in Postwar Britain (Houndmills: Palgrave, 2016). For responses to Wolfenden in New Zealand, see J.E. Bennett, 'Keeping the Wolfenden from the Door? Homosexuality and the "Medical Model" in New Zealand', Social History of Medicine, 23 (2009), 134-52.
} 
qualifying comments about homosexuality in order to maintain an acceptable distance from such a stigmatised identity. ${ }^{39}$ Two important early supporters of reform adopted this standpoint. They were Venn Young and the Hon. Dr Martyn Finlay, a key frontbencher in the Labour government of 1972 to 1975. Finlay was one of the first MPs to support reform, and he also viewed homosexuality through a medical lens. ${ }^{40}$ Indeed, Finlay's emphasis on the need for psychiatric intervention as a diagnostic tool is a striking feature of his comments on the failed New Zealand Homosexual Law Reform Society (NZHLRS) petition to Parliament in 1968. Finlay suggested homosexuality was 'a symptom of a sickness less of the body than of the mind' ${ }^{41}$ But this cut both ways. Medical discourses were also mobilised by anti-reformers who harnessed any moments of medical uncertainty about the 'homosexual condition' as a barrier to wide-ranging legal reform. Anti-reformers represented non-normative sexuality as evidence of an aberrant mind that required 'counselling or professional psychiatric intervention', not a free pass. ${ }^{42}$

When Venn Young introduced the Crimes Amendment Bill to the House in July 1974 he was himself a recent convert to the campaign for reform. This had come about in part through his contact with the politically moderate and pragmatic NZHLRS. Formed in 1967, this society shared its British counterpart's name and exemplified the collaboration between prominent liberal heterosexuals and homosexual activists. Many MPs acknowledged Young's moral courage in sponsoring the Crimes Amendment Bill. ${ }^{43}$ This provided for decriminalisation of consenting adult acts in private, setting the age of consent initially at twenty-one years. The age was amended to twenty during the first reading of this private members' bill. The bill met with defeat during the second reading although by the relatively narrow margin of thirty-four to twenty-nine with a significant number of MPs - twenty-four - simply not voting. ${ }^{44}$ Emergent gay liberation groups, which rose to prominence in 1972, took a more insistent line on political reform than the older NZHLRS, and consensus over the legal age of consent proved impossible to reach. Gay liberationists argued that as sixteen was the age of consent for girls in heterosexual encounters, the same age should apply between males. A lack of agreement on this issue hampered the reform movement, and it sealed the fate of two later reform bills sponsored by backbench Labour MP Warren Freer in 1979 and $1980 .{ }^{45}$ Public opinion polls conducted in this period suggested a favourable political climate for reform, but this was not a passionately held majority view and few parliamentarians felt any need to rethink their position. ${ }^{46}$ The Gay Liberation Front's monthly newsletter Aequus concluded that parliament was only one site of power and influence and that lobbying had to be targeted much more broadly. Aequus's editor wrote:

${ }^{39}$ See editorial comment on Crimes Amendment Bill (1975), Aequus, 2 (July 1975), 1.

${ }^{40}$ C. Burke, Diversity or Perversity? Queer Narratives, Resistance and Representation in New Zealand, 19482000 (Saarbrücken: Verlag Dr Müller (VDM), 2009), 44, 64, 81.

${ }^{41}$ Star, 8 November 1968, Homosexuality - newspaper clippings and reports. Leonie Jean Neill. LAGANZ-MSPapers-579-03, ATL.

42 Burke, op. cit. (note 40), 49-50. Logan, op. cit. (note 1).

${ }^{43}$ Auckland University Gay Liberation. Submissions to the Parliamentary Select Commitee [sic] on the Crimes Amendment Bill 1974. (Auckland, 1974), 2.

${ }^{44}$ L. Guy, Worlds in Collision: The Gay Debate in New Zealand 1960-86 (Wellington, NZ: Victoria University Press, 2002), 83.

${ }^{45}$ C. Brickell, Mates and Lovers: A History of Gay New Zealand (Auckland: Random House, 2008), 298.

${ }^{46}$ Guy, op. cit. (note 44), 87. 
[We seek] the education of people like the clergy, doctors, psychologists, teachers and social workers, whose attitudes have a very great effect both on public awareness of gay problems and on individuals themselves. ${ }^{47}$

Of the MPs who took part in parliamentary debate on the bill, a number framed their contribution around medical discourse. Some drew on alleged medical 'expert authority' to refute newer medical ideas in professional psychiatric circles and reassert the efficacy of traditional treatment procedures. ${ }^{48}$ The most prominent speaker to take this line was the minister of police in the centre-left Labour government, Michael (Mick) Connolly, who asserted bluntly that ' $[\mathrm{h}]$ omosexuals require medical treatment, not a change in the law' ${ }^{49}$ The police minister bolstered his argument by drawing upon the medical authority of an Australian clinician named John Court who remained resolute in championing the efficacy of treatment. Connolly's prominence as a Government minister, combined with his uncompromising hostility to reform, earned him the chastisement of a gay liberation movement that had few avenues to publicly challenge such prejudice ${ }^{50}$ As a consequence, the criticisms were mostly confined to media produced within the context of gay liberation and circulated within the gay community.

Perhaps the most extraordinary phase in the unsuccessful passage of the 1975 Crimes Amendment Bill through the House was the amendment proposed by Dr Gerald Wall, a surgeon and Labour MP for the electorate of Porirua. ${ }^{51}$ Wall insisted there was no scientific evidence that sexual identity was set in the early years, leading him to the conclusion that the environment could be an influence on teenage behaviour. He claimed to have evidence of the 'proselytisation' of homosexuality in high schools by pro-reform groups. Wall was not wholly wrong in this regard: feminist and gay liberation groups did indeed talk to secondary school pupils about sexuality, sometimes urging them to throw off the shackles of conservative social mores. ${ }^{52}$ The broader social context for such interventions included steadily improving access to contraception and modernisation of the abortion laws, issues that vexed the conservatively minded like Wall. ${ }^{53}$ Along similar lines, Truth newspaper - a tabloid newspaper known for its scandalmongering - complained about 'social engineering of the young by trendies and the sexually sick'. ${ }^{54}$ Wall's amendment proposed that anyone who told young people under the age of twenty that homosexuality was 'normal' would be an act punishable by a prison term of two years. Only doctors and ministers of religion would be exempted. ${ }^{55}$ Unsurprisingly, the Wall Amendment drew criticism both within and

\footnotetext{
${ }^{47}$ Editorial, Aequus, 3 (May 1976), 5. 'Aequus' is a Latin word that translates here as 'equality'. The community newsletter proclaimed its mission as one dedicated to 'the rightful equality of gay men and women with all other men and women'.

${ }^{48}$ See, for example, Patrick Blanchard in New Zealand Parliamentary Debates (NZPD), 399 (3 July 1975), 2773 and the Hon. Michael Connolly in NZPD, 399 (3 July 1975), 2779-80. Unlike most democracies, New Zealand has a unicameral legislature, which meant that all parliamentary debate occurred in the House of Representatives. 49 Connolly, ibid., 2779. Although Connolly was not more specific in his attribution of this line of argument, it is likely he was referring to Flinders University psychologist, Dr John Court, who was an 'outspoken' member of the 'evangelical' Moral Action Committee. See C. Parker and P. Sendziuk, 'The Duncan case and the decriminalisation of homosexual acts in South Australia 1972', in Smaal and Willett, op. cit. (note 14).

${ }^{50}$ Aequus, 5 (February 1978), 9.

${ }^{51}$ Wall would go on to be Speaker of the House of Representatives from 1985 to 1987.

52 C. Brickell, 'Sex Education, Homosexuality and Social Contestation in 1970s New Zealand', Sex Education, 7 (2007), 391.

53 C. Brickell, 'Sexuality, morality and society', in G. Byrnes (ed.), The New Oxford History of New Zealand (Melbourne: Oxford University Press, 2009), 465-86.

${ }^{54}$ New Zealand Truth, 10 July 1979, 4.

55 Dr Gerald Wall, 3 July 1975, NZPD, Vol. 399, 2786-8.
} 
outside Parliament for its planned curtailment of free speech, and for failing to discriminate between qualified and unqualified medical and religious opinion. ${ }^{56}$

At least one academic responded with unease to the Wall Amendment. Chris Dearden, Professor of Classics at the Victoria University of Wellington, suggested a wholesale ban on literature that accepted homosexual behaviour was normal would 'obviously deprive us of almost the whole of Greek and Roman literature which accepts bisexuality as a matter of course, normally without comment' ${ }^{57}$ Dearden rejected medical arguments and drew, if only implicitly, upon a classical discourse with a much longer history in gay male communities themselves. Men talked and wrote of 'Greek love', drawing on sources like Plato's Symposium which told of 'virtuous lovers' and 'beloved youth'. These ranged from European writers such as John Addington Symonds, whose A Problem of Greek Ethics from 1873 defended same-sex love, to New Zealanders who wrote about Greek love in letters and diaries. ${ }^{58}$ The old and the new came together: appeals to the classical world provided one way to resist the medicalising moment at the same time that conservative parliamentarians railed against the evils of the modern world.

To return to Willett's point about the contrasting nature of the psychiatric profession in North America on the one hand and Australia and New Zealand on the other, it is clear that although there were several blocs of opinion by the early 1970s within the ANZCP on responses to homosexuality, the absence of deeply entrenched theoretical positions in the antipodes modified the nature of the relationship between medicine and gay activism. New medical knowledge, for instance, could be readily harnessed in New Zealand to refute expedient appeals to old medical orthodoxies by politicians when medicine and the law intersected as they did during the unsuccessful passage of the Crimes Amendment Bill. In this way, psychiatry was part foe, part ally in the hegemonic struggle over medical knowledge that characterised the shifting currents of social politics in the 1970s.

\section{Gay Liberalisation and De-medicalisation}

Resistance to medicalisation by gay groups and individuals has been largely overlooked by New Zealand historians. Yet, as in other western countries, gay voices were an integral part of the slow march towards de-medicalisation, a process that became turbocharged during the 1970s as the scope of activism widened and activists became more forthright in expressing their views. As Willett has explained in the Australian context, the momentum for change owed much to the 'interlocking processes' of gay liberation and liberalism. ${ }^{59}$ Despite some obvious differences between these twin forces, a consensus emerged around the goals of law reform and tolerance. Law reform in the $1960 \mathrm{~s}-$ a period sometimes characterised as the era of the 'homophile movement' - involved an alliance forged between homosexual activists, who were moderate in their demands, and a select group of progressive-thinking heterosexuals who had a high public profile. These notables included: Reverend Felix Donnelly; the politician, the Hon. Dr Martyn Finlay; the sociologist,

\footnotetext{
${ }^{56}$ Venn Young, 3 July 1975, NZPD, Vol. 399, 2767. 'The Crimes Amendment Bill', Aequus, 2 (June 1975), $10-12$.

57 C.W. Dearden to Robert Muldoon, 29 May 1975, Personal Papers of Professor Anthony J.W. Taylor relating to Homosexual Law Reform, 1962-75, LAGANZ-MS-Papers-294, ATL.

${ }^{58}$ R. Aldrich, Seduction of the Mediterranean: Writing, Art and Homosexual Fantasy (London: Routledge, 1993); S. Brady, John Addington Symonds and Homosexuality: A Critical Edition of Sources (New York: Palgrave, 2012); Brickell, op. cit. (note 45), 49-50 and passim.

59 Willett, op. cit. (note 14), 104, 107.
} 
Professor Jim Robb; the psychologist, Professor Tony Taylor; and Dr Don Mathieson, a legal academic. ${ }^{60}$

The liberal, pragmatic reform agenda exemplified by the NZHLRS increasingly gave way by the mid to late 1970 s to a more strident political message promoted by rival groups, and the tensions over approaches to reform - and wider social strategies - were palpable. The National Gay Rights Coalition (NGRC), an activist alliance formed in 1977 that comprised more than thirty groups, openly challenged the prejudiced utterances of politicians and public officials. The NGRC's manifesto challenged 'repressive laws; discrimination; social attitudes causing fear, guilt, shame and loneliness; sexism and sexual stereotyping', ${ }^{61}$ The objectives of gay liberation, then, extended well beyond decriminalisation: challenging and overturning the 'sickness' paradigm, and the fear, guilt and shame that underpinned it, were also key goals. The NGRC recognised the importance of providing professional services - particularly doctors and counsellors - who responded sympathetically to gay people, and it promoted the following message through the gay press:

Groups are asked to contact local 'good' doctors and lawyers with a view to drawing up a list of supportive professionals in each regional area. This list will not be advertised but issued on a restricted basis to group secretaries for the use of people in need. If you know of a doctor or lawyer who would be supportive please ask them if they could also recommend colleagues in out-of-the-way areas. Names and addresses to Secretary, NGRC. ${ }^{62}$

Gay liberation groups, some of them formed on New Zealand's university campuses and others established through community networks in regional towns, were also at the vanguard of political reform. Although the movement in New Zealand could not claim anything as specific in focus as the Counter Psychiatry Group, which formed as a division of the Gay Liberation Front in Melbourne, activists were nevertheless cognisant of the power of medical definitions on public opinion. ${ }^{63}$ They also resisted the ways law and medicine represented 'interlinking patterns of knowledge and control', to borrow from Turkel's Foucauldian analysis. ${ }^{64}$ In July 1974, for instance, Victoria University's gay liberation group arranged a press release challenging comments made by then opposition leader, Robert Muldoon - who later became prime minister - on a radio talkback show. Muldoon claimed "the homosexual "is not a very happy person" and "is not in essence a normal person"”, and he accused gay liberationists of 'antisocial' behaviour and 'exhibitionism'. ${ }^{65}$ These were febrile years politically, with members of parliament - backbencher Marilyn Waring from the centre-right National Party was the most well-known - 'outed' sensationally by the newspapers. Others became the subject of speculation. ${ }^{66}$ A Victoria University gay liberation press release, signed by President Rae Dellaca, chastised Muldoon for his apparent refusal to take account of doctors, a group manifestly more qualified to make pronouncement on this subject than politicians.

${ }^{60}$ Donnelly was the most multifaceted of this group of eminent supporters. He was variously a Catholic priest, academic in the field of health sciences, writer, social activist and commentator - particularly on issues related to human sexuality.

61 Aequus, 6 (September 1979), 10.

62 Ibid., 5 (March 1978), 4.

${ }^{63}$ Willett, op. cit. (note 14), 104.

64 Turkel, op. cit. (note 30), 172.

65 Salient, 37 (1974).

66 See, for instance, J. Aitken, 'Exposé: The "Moyle Affair" in Public Discourse' (BA Hons dissertation, University of Otago, 2011); New Zealand Truth, 24 August 1976, 1; New Zealand Truth, 18 January 1977, 1 and 3 . 
The Victoria gay liberation group also criticised the Labour prime minister, Norman Kirk, who voiced his antagonism toward homosexuality by claiming it was 'unnatural' and 'not normal' 67

In challenging leading politicians of the day, gay liberationists questioned the then influential 'normative' view of disease which closely correlated illness with undesirability. ${ }^{68}$ Zeroing in on some parliamentarians' claims that homosexuality was not a normal state of being, the gay liberation press release quoted Dr Erich Geiringer, founder of the New Zealand Medical Association ${ }^{69}$, who pithily observed that "neither is having varicose veins normal, and it is considerably more costly to the taxpayer than homosexuality'. ${ }^{70}$ This use of parody and an emphasis on word play - particularly with respect to such a value-laden term as 'normal'- were key tools in the arsenal of gay liberation.

Guilt and shame exacted a heavy toll on individual lives, and this encouraged gay liberationists to resist aspects of moral and medical discourse. ${ }^{71}$ Not only did the gay liberation movement aim to bring about a shift in the attitudes and practices of the psychiatric profession, but its members also sought to change the social and political climate so people experiencing same-sex desires no longer felt compelled to come forward and have their desires clinically treated. Psychiatrists in the anglophone world reported a sharp drop in the numbers of patients presenting for treatment over the course of the 1970s. A number of factors account for this shift including the long-term ineffectiveness of aversion therapy and other treatments. ${ }^{72}$ Gay community initiatives, especially the movement for gay pride, also influenced this trend. ${ }^{73}$ As a political movement, gay pride was 'premised on the eradication of shame'. ${ }^{74}$ In the decades since, a number of further legislative changes - the Homosexual Law Reform Act decriminalised sex between men in 1986, discrimination on the basis of sexuality was outlawed in 1993, and Parliament passed marriage equality legislation in 2013 - can be seen as major milestones in this gradual process of purging shame. ${ }^{75}$

Medicalisation and de-medicalisation took a further twist. During the 1970s, when gay liberation groups sought to ameliorate the impact of shame on individual lives, they actively engaged with psychological discourses. The newsletter Aequus included a review of Society and the Healthy Homosexual, a book by the North American psychotherapist Dr George Weinberg, published in 1972, in which the author was the first to expound the concept of 'homophobia'. ${ }^{76}$ In the discussion of a father-son relationship, Weinberg

\footnotetext{
${ }^{67}$ Open letter from Rae Dellaca, President Gay Liberation, VUW Students' Association to Norman Kirk, PM, 9 July 1974. Gay Liberation Wellington, 1972-5. Correspondence 1972-5. LAGANZ-MS-Papers-77-04, ATL.

${ }^{68}$ S. LeVay, The Use and Abuse of Research into Homosexuality (Cambridge, MA: MIT Press, 1996), $213-4$.

${ }^{69}$ A local branch of the British Medical Association was founded in New Zealand in the late nineteenth century, which continued until 1967.

70 Gay Liberation (VUW Students' Association) Press release, 10 July 1974. Gay Liberation Wellington, 1972-5. Press releases. LAGANZ-MS-Papers-77-06, ATL.

${ }^{71}$ On guilt and shame in patients presenting to psychiatrists, see D.J. West, Homosexuality: A Frank and Practical Approach to the Social and Medical Aspects of Male Homosexuality (Harmondsworth: Penguin, 1960), 47-8.

72 On the latter see, for instance, L. Featherstone and A. Kaladelfos, Sex Crimes in the Fifties (Melbourne: Melbourne University Press, 2016), 176-8.

73 Willett, op. cit. (note 14), 107.

${ }^{74}$ E. Probyn, Blush: Faces of Shame (Minneapolis, MN: University of Minnesota Press, 2005), 2.

${ }^{75}$ B. Brookes, 'Shame and its Histories in the Twentieth Century', Journal of New Zealand Studies, 9 (2010), 41.

${ }^{76}$ Altman, op. cit. (note 16), 12.
} 
isolated the real problem as the father's homophobia rather than his son's homosexuality. He showed how 'feelings of shame and guilt arise in the first place' and then offered a strategy for ridding the self of internalised homophobia. Aequus's reviewer endorsed Weinberg's perspective. ${ }^{77}$ The use of the term 'homophobia' represented a key resistance strategy of gay liberation, one that sought to invert power relations by casting the homophobe - not the homosexual - as the person in need of a 'cure'. This linguistic manoeuvre is an example of Foucault's 'reverse discourse' in which homosexuality speaks on its own behalf, 'often in the same vocabulary, using the same categories' - in this case pathology and cure - 'by which it was medically disqualified'. ${ }^{78}$ This was a tangled knot. Gay liberationists did not reject all psychiatric discourse on homosexuality, only that discourse they perceived as oppressive. Some psychiatrists, including Weinberg, offered new tools - in this case the concept of 'homophobia' - that proved useful in re-framing the relationship between homosexuality and mental health.

Similarly, Ian Hacking's concept of 'looping effects' provides us with a valuable insight into understanding the relationship between homosexuality and classification systems. According to Hacking, fresh classifications - including the idea that homosexuality is a transient mental illness - conjure new kinds of people into being, a process he calls 'making up people'. Classification is a reciprocal process: not only do classifications affect the people who are 'made up', but those people in turn affect classifications. Hacking identifies ten imperatives that have driven the human sciences over the past two hundred years. The need to medicalise, he suggests, is one of seven engines of discovery. A well as propelling knowledge these imperatives also underpin the making up of people and looping effects. The last such effect is resistance against classifications and stereotypes. By this analysis, '[g]ay pride and its predecessors restored to homosexuals control of the classifications into which they fall' ${ }^{79}$ This resistance, and its contested place in a complex set of movements and counter-movements, has been an important part of the story of gay politics and gay identity itself.

\section{Reverse Discourse and Medical Opinion}

Resistance to oppressive kinds of medical discourse took a range of forms in New Zealand during the 1970s. In a tacit acknowledgment of the power of medical views to influence public opinion, gay reviewers in Aequus vigorously debunked negative representations by medical writers. The reviewer of Walter C. Aluarez's book, Gay Liberation vs Homosexuality, for example, took the author to task for suggesting 'sexual deviates' suffered an 'inborn peculiarity of the brain'. 'His diagnosis of homosexuality gives me the guts-ache', the reviewer wrote, bluntly adding that Aluarez 'is another doctor whom we could well do without as a specialist spokesman on homosexuality'. ${ }^{80}$ To borrow Hacking's metaphor, the writer would not agree to be made up as a person in the way a writer like Aluarez thought he should.

Those who wrote for Aequus also quoted relevant passages from prominent documents. A case in point was the controversial Australian Royal Commission on Human Relationships, constituted in 1974 by the Whitlam government that went on to submit

\footnotetext{
77 Aequus, 2 (August 1975), 7-8.

${ }^{78}$ M. Foucault, The History of Sexuality, Vol. 1: An Introduction (London: Penguin, 1978), 101.

${ }^{79}$ I. Hacking, 'Kinds of people: moving targets', Proceedings of the British Academy: 2006 Lectures (Oxford: Oxford University Press, 2007), 285-318 and 466-7.

${ }^{80}$ Aequus, 3 (March 1976), 14.
} 
a final report in 1977. Various sections of this landmark five-volume report referenced attitudes to homosexuality. While not denying the existence of dissenting voices, the Royal Commission was unambiguous in its statement of opposition to medical treatment regimes, based on the evidence heard.$^{81}$ Aequus told its readers about the Commission's findings. Those recommendations included reference to the official position of the ANZCP that called for law reform in relation to consenting same-sex acts between adults in private; sex education directed 'to children in schools, to parents, teachers and medical students about homosexuality' involving 'selected' homosexual people to 'help eliminated [sic] prejudice and discrimination', and the provision of 'well-informed and sympathetic counselling services' for homosexuals. ${ }^{82}$

At an individual level, some gay people refused to accept the popularly voiced, medically based prejudices of the mainstream press and its correspondents. J.L. of Wellington, for instance, wrote in forceful terms to the editor of Truth:

I have been reading for some time in your publication other people's opinions of homosexuality and its society... What makes some readers think we want to be cured? Have they ever considered that homosexuality is, to some members of society, an alternative to heterosexuality, and is not abnormal? ... The only bar to our happiness is the opinion of society... This country's laws deny us legality, and churches refuse to bless our unions - why? In the street where we live we are accepted as married and gay. ${ }^{83}$

Once again, one kind of making of the homosexual - as an abnormal social outcast - was rejected here. But gay liberationists' reverse discourse - that is, their more radical re-working of psychiatry - did not dislodge prevailing assumptions among doctors, at least not initially. In 1976 law reform advocate Felix Donnelly, then senior lecturer in community health at Auckland Medical School, claimed that three-quarters of psychiatrists and psychologists still saw homosexuality as 'an anomaly' rather than a social problem marked by a lack of public acceptance. Only a quarter, he felt, believed in helping their patients to adjust to their sexuality and remove the guilt and fear that plagued their lives. ${ }^{84}$ The Auckland University gay liberation group made the same estimation, drawing upon figures supplied by Professor Schaeffer, clinical psychiatrist at the Auckland Medical School. ${ }^{85}$ As a profession, psychiatry was still divided over the aetiology of homosexuality and the appropriate response to it. After all, beneath the American Psychiatric Association's 1973 decision to remove homosexuality from the DSM-II lay a significant body of dissent: no less than thirty-seven per cent of respondents adhered to the old listing. To assuage conservative members, many of them analysts and behaviour therapists, the APA's board developed the new category of 'sexual orientation disturbance'. This would apply to 'individuals whose sexual interests are directed primarily towards people of the same sex and who are either disturbed by, in conflict with, or wish to change their sexual orientation'. ${ }^{86}$

By the late 1970s law reform advocates in New Zealand acknowledged that the ANZCP (renamed the 'Royal Australian and New Zealand College of Psychiatrists' in 1978) now believed that its role was principally one of assisting the patient to become 'a better adjusted homosexual' rather than attempting to suppress sex drive or altering sexual

${ }^{81}$ See, for example, ibid., 5 (June 1978), 18.

82 Aequus 5 (June 1978), 17.

83 'Gay Way - Why Persecute Us?', New Zealand Truth, 16 November 1976, 45.

${ }^{84}$ F.C. Donnelly, 'The Doctor and the Homosexual', New Zealand Medical Journal, 83 (1976), 323.

85 Auckland University Gay Liberation, op. cit. (note 43), 4.

${ }^{86}$ LeVay, op. cit. (note 68), 224. See letter from APA to Paul R. Smith, 29 December 1976 with attached press release dated 15 December 1973, LAGANZ-MS-Papers-514, ATL. 
orientation. ${ }^{87}$ Treatments were still available from the clinician - but now on a strictly voluntary basis. Donnelly had long recognised the need for training in social medicine that would encourage medical practitioners to develop deeper insights and improve their professional encounters with patients. ${ }^{88}$ Equally, gay liberation became acutely aware by the mid to late 1970 s of the vital need for professional counselling and support services for expanding numbers of gay people, many in heterosexual marriages, who were attempting to come to terms with their sexuality. This was a controversial area for some in the formal health system and not one in which some practitioners and counsellors had adequate training. ${ }^{89}$ To this end, a Wellington gay liberation group surveyed Fellows of the ANZCP in 1977 to evaluate attitudes of psychiatrists to their homosexual patients and to 'assess back-up services desirable to assist psychiatrists in the care of these clients' ${ }^{90}$ The questionnaires yielded fertile data - both quantitative and qualitative - and provide at once a unique and illuminating insight into the attitudes of practitioners in 1970s New Zealand, about whose perspectives and experiences very little is known.

Wellington gay liberationists sought to gauge the views of Fellows of the ANZCP based around New Zealand, although the survey response rate was only about fortyfour per cent, a much smaller sample group than the College's survey of New South Wales practitioners in 1973. In line with Donnelly's 1976 claim, fewer than one-third of respondents considered homosexuality to be a normal variant of sexuality. The majority regarded it as an abnormal deviancy while a few situated it in the category of 'other', in the process revealing a wide spectrum of opinion on aetiology. 'Childhood maladjustment' and 'arrested sexual development' were believed to be the most common causes while several saw the phenomenon as multifactorial or reasons varied from one client to another. Approximately half considered electroconvulsive therapy (ECT) to be an inappropriate or unethical 'cure' but only a little over ten per cent felt the same about aversion therapy - that bête noire of treatments for gay liberationists in the 1970s. ${ }^{91}$ A similar result was recorded for opinion on the use of drug therapy. Even by the late 1970s, then, there was still a deep gulf in perspective on some issues between many clinicians and the gay movement. Gay liberation drew with alacrity on the written opinion of one particular medical voice, that of Dr Stanley-Jones who declared that 'attempted treatment or alteration of the basic personality of an inborn homosexual can be described as a moral outrage'. ${ }^{92}$

The ANZCP questionnaire provided scope for qualitative input and many respondents took up this opportunity. Their responses produced some revealing patterns. A number explicitly supported law reform, and some felt that the social climate of society presented the most serious obstacle to adjustment. A very common response by College Fellows and one widely mirrored in the literature - lay in the fact that the clinician's perspective was significantly skewed by the over-representation of a particular type of homosexual patient: those who presented were often in treatment for a range of maladies, not primarily

${ }^{87}$ Information flyer prepared by National Gay Rights Coalition of NZ, 1978. Wellington Gay Liberation Papers 1976-81. LAGANZ-MS-Papers-77-32 relating to 1978 National Gay Rights Coalition survey of electorates, ATL.

${ }^{88}$ F. Donnelly, 'Factors in the homosexuality of some New Zealand males' (Photocopy of thesis for Diploma in Criminology, 1970). Chris Parkin Papers. LAGANZ-MS-Papers-109-14, ATL.

${ }^{89}$ Michael Waghorne to Mental Health Foundation. Waghorne Correspondence 1977-83. LAGANZ-MS-Papers517, ATL.

${ }^{90}$ Survey letter, 21 April 1977. Dudley Pollard, Coordinator, Gay Liberation Wellington. Return on Survey of RNZCP, LAGANZ MS-Papers-77-28, ATL.

91 Return on Survey of RNZC Psych, ibid.

92 National Gay Rights Coalition of NZ 1978, op. cit. (note 87). 
their sexual orientation..$^{93}$ Or, as one Wellington GP had put it succinctly in a published paper almost a decade earlier, "psychiatrists do not see typical homosexuals, but only homosexuals with other problems'. ${ }^{94}$ This fact led a few respondents to openly challenge the methodology of the survey that, in the view of one, focused on a single behaviour taken out of context. Another provided the following rebuke to the survey designers: 'As I do not set out to treat homosexuals as such many of the questions are irrelevant' ${ }^{95}$ In an identical 1977 survey of a smaller sample group of Wellington-based psychiatrists and psychologists, many of whom did not have relevant clinical experience to draw on, the majority saw homosexuality as a normal variant of sexuality, some framing it explicitly as a social rather than a sexual issue. There was practical unanimity in this group that ECT was unethical or inappropriate and, consistent with College Members, fewer had the same opinion on the use of aversion therapy and drug treatment. ${ }^{96}$

Medical opinion had not shifted as dramatically as gay liberationists would have liked over the course of a decade, and this is illustrated most strikingly by professional opinion recorded through these surveys on the ethics of aversion therapy, medicine's most commonly used mid-twentieth century 'cure' for the sexual behaviour of gay men like Ralph Knowles. At the same time, by 1977 many in the profession recognised that a search for 'cures' was misguided and agreed that the best form of professional support lay in the area of social adaptation. This fed into a broader mood for law reform identified by gay liberation groups when they polled citizens in urban electorates around New Zealand in 1978. The next stage of the battle would be fought on the rocky terrain of social and legal reform during the 1980s.

\section{Conclusion}

We can draw a number of conclusions about medicine, shifts in medical opinion and the use of medical arguments in relation to homosexuality in the 1970s. First, this was a decade of enormous flux both politically and socially, embodied most dynamically in the growth of the gay liberation movement. While the larger and better organised gay liberation movements in other anglophone societies revealed a greater degree of resistance to medicalisation, the influence of gay liberation is nevertheless discernible in the New Zealand context. Second, change was also occurring in psychiatric circles at this time, to some extent in response to the changing social and political climate. 'Expert medical opinion' was ostensibly premised on the tradition of impartiality and objectivity, but this hardly took shape in a social vacuum. ${ }^{97}$ As Michael King and his colleagues have argued in a joint paper, 'liberalisation of public attitudes to homosexuality show how social and moral attitudes can determine what is regarded as a "pathology". 98

Medical knowledge about homosexuality was at a crossroads during the 1970s, and the cracks in physicians' veneer of unanimity widened even further. The issue was subject to increasing public debate at a time when parliamentarians took an interest in the legal status of homosexuality, and this inevitably influenced doctors' and psychiatrists' views. As one

\footnotetext{
93 Return on Survey of RNZC Psych, op. cit. (note 90).

${ }^{94}$ Philipp, op. cit. (note 27), 401.

95 Return on Survey of RNZC Psych, op. cit. (note 90).

96 Return on Survey of RNZC Psych, op. cit. (note 90).

${ }^{97}$ Donnelly, op. cit. (note 84), 323. Bennett, op. cit. (note 38), especially 146. J. Terry, American Obsession: Science, Medicine and Homosexuality in Modern Society (Chicago: University of Chicago Press, 1999), 11-12.

${ }^{98}$ King, Bartlett and Glennie, op. cit. (note 6).
} 
Wellington practitioner commented when surveyed in 1977, homosexuality was 'a woolly area with great conflict of attitudes \& theory \& too little hard data. Probably representing the confusions of our time'. ${ }^{99}$

In one sense, the events of the 1970s represent a power contest. Some doctors maintained the right to 'treat' homosexual patients - some of them did so in the same way Basil James 'treated' Ralph Knowles in 1964 - but also to uphold the idea that illness or psychological maladjustment defined homosexuality itself. At the same time, gay liberationists rejected the very idea that homosexuality was less natural or healthy than heterosexuality. Some went even further, arguing that the very classification of people into sexual categories in the first place revealed the operation of oppressive social practices. ${ }^{100}$ Some activists turned the medical masters' process of definition against them: if anybody suffered from an illness, and needed a cure, it was the 'homophobe'. At stake in this contest of Foucauldian reverse discourses was the power to define a particular mode of being (homosexuality) and knowledge (a particular set of medical presumptions about homosexuality) as acceptable or unacceptable, normal or deviant. As Hacking would suggest, gay activists took control of the kinds of classifications in which homosexuality had been constructed.

This was a tangled web. When a doctor surveyed by the Wellington gay liberation group stated 'I do not set out to treat homosexuals', he rejected any assumption that as a medic he would want to change his patients' sexual orientation. Yet in resisting the wording of the question he tacitly confirmed the aim of the questionnaire in the first place: to seek out and tabulate justifications for a (medical) course of action that gay liberation groups found morally and politically unacceptable. Doctors did not lie on one side of the argument and gay activists on the other, but sometimes arguments crisscrossed. They had done since the 1960s, when some of those who lobbied for reform of the sexuality laws deployed medical ideas in order to do so. Those who suffered a sickness, suggested parliamentarian Martyn Finlay and others, could not be held morally culpable for their actions - and the law should not discriminate against them. Some conservatives, in contrast, suggested illness required treatment, not a law change. The relationship between medicine and law was a complex one. The impact of gay liberation during the 1970s saw this argument about medical treatment versus legalisation lose ground, but the imbrication of medical and liberal views continued. Gay groups told of the need for counselling for members of a socially marginalised population who suffered shame. Further debate over homosexual law reform during the mid-1980s saw the concept of homophobia deployed to apply stigma in reverse to those uncomfortable with gay lives. Medical ideas, notions of moral corruption, discourses of shame and pity, and debates over freedom and social transformation all jostled for attention - and influence - during the 1980s. ${ }^{101}$ When Ralph Knowles remembered his aversion therapy ordeal in 1964 and reflected upon it in several publications, he inserted his earlier experiences into new debates about homosexuality, medicine and their complicated relationship.

Homosexuality and its 'treatment' is not an issue solely confined to past societies. While aversion therapy is now discredited in the West, its continuing use in some nonWestern countries such as China has been documented notwithstanding that country's

${ }^{99}$ Gay Liberation Wellington, Survey of Psychiatrists and Psychologists 1977, LAGANZ MS-Papers-077-27, ATL.

${ }^{100}$ Brickell, op. cit. (note 45), ch. 5.

${ }^{101}$ Logan, op. cit. (note 1), 2. 
removal of homosexuality as a psychiatric disorder in $2001 .{ }^{102}$ Moreover, conversion therapy - generally known as 'reparative therapy' - continues to be practised particularly in the United States. As King and Bartlett have observed in relation to British practice, 'assumptions in psychoanalysis and the behavioural sciences that sexuality could be altered led to unscientific practice'. ${ }^{103}$ Alan Turing, the English mathematician, Second World War codebreaker and computer pioneer, is the most celebrated example of a gay man who was subjected to therapy - in his case, hormonal treatment - which proved a major factor in his decline and ultimate death in $1954 .{ }^{104}$ Others have come forward more recently to testify to the long-term destructive impact of therapies on their lives. ${ }^{105}$ The work of King, Bartlett and others has been very explicit in using this cautionary story in an effort to repair the relationship between gay and lesbian patients and their psychiatrists and to 'prevent future excesses'. ${ }^{106}$ Although no psychiatric body has ever offered an official apology for the actions of its members in relation to the catalogue of 'cures' inflicted on patients and their ongoing consequences, in an official position statement in April 2014, the Royal College of Psychiatrists (UK) nevertheless took a critical step in decisively rejecting conversion therapies. ${ }^{107}$

\footnotetext{
${ }^{102}$ For a more general discussion of psychiatry and the manufacture of mental illness in 21st-century China, see H. Yi-Jui Wu, 'The Moral Career of Outmates: Towards a History of Manufactured Mental Disorders in Post-Socialist China', Medical History, 60 (2016), 87-104.

103 M. King and A. Bartlett, 'British Psychiatry and Homosexuality', British Journal of Psychiatry, 175 (1999), $106-13$.

${ }^{104}$ In 2009 the British prime minister, Gordon Brown, issued an unequivocal apology for the treatment of Turing. This was followed in 2012 with a posthumous Royal pardon for his conviction in 1952 for 'gross indecency'.

105 See, for example, Patrick Strudwick, 'This Gay Man Was Given Repeated Electric Shocks by British Doctors to Make Him Straight', BuzzFeed, 30 September 2017, https://www.buzzfeed.com/patrickstrudwick/this-gayman-was-given-repeated-electric-shocks-by-british?utm_term=.ppv2X8bMr\#.ehOZVyEgB (accessed 2 October 2017).

106 King and Bartlett, op. cit. (note 103), 111.

107 Royal College of Psychiatrists' Statement on Sexual Orientation, Position Statement PS02/2014, April 2014. https://www.rcpsych.ac.uk/pdf/PS02_2014.pdf (accessed 3 October 2017).
} 